\title{
Struktur Komunitas Bivalvia di Pantai Juata Laut, Tarakan, Kalimantan Utara
}

\author{
Bivalvia Community Structure in Juata Laut Beach, Tarakan, North Borneo
}

Agustinus Toding Bua

Universitas Borneo Tarakan, FKIP, Jl. Amal Lama No.1

E-mail: agustinust31@gmail.com

\begin{abstract}
Bivalves are a group of marine biota as an important component of aquatic ecosystems. Bivalves are one of a group of invertebrate organisms that are found and live in coastal areas. Pantai Juata Laut Tarakan is one of the excellent Bivalvia deployments. Increased exploitation of Bivalves into foodstuffs in Tarakan City is one of the factors that resulted in the decline in Bivalvee population. The purpose of this study is to study the structure of community and pattern of Bivalvia distribution in Tarakan Juata Sea Beach. The method used is Belt Transects by plot size 1x1 meter. The Bivalvia Community in Pantai Juata Laut consists of Anadara granosa and Polymesoda erosa. The distribution pattern of Bivalves in the location is uniform. The measurement of environmental parameters shows substrate composition at Pantai Juata Laut in the form of sandy mud which has many organic content. The quality of the waters at this location is still quite good for the life of Bivalvia.
\end{abstract}

Keywords: Bivalves, Diversity, Density, Distribution, Physico-chemical Factors

\begin{abstract}
Abstrak
Bivalvia merupakan kelompok biota laut sebagai komponen yang penting penyusun ekosistem perairan. Bivalvia merupakan salah satu kelompok organisme invertebrata yang banyak ditemukan dan hidup di daerah pesisir pantai. Pantai Juata Laut Tarakan merupakan salah satu penyebaran Bivalvia yang sangat baik. Meningkatnya eksploitasi Bivalvia menjadi bahan makanan di Kota Tarakan merupakan salah satu faktor yang mengakibatkan penurunan populasi Bivalvia. Tujuan penelitian ini untuk mempelajari struktur komunitas dan pola sebaran Bivalvia di Pantai Juata Laut Tarakan. Metode yang digunakan adalah Belt Transects dengan membuat plot ukuran 1x1 meter. Komunitas Bivalvia di Pantai Juata Laut terdiri dari Anadara granosa dan Polymesoda erosa. Pola sebaran Bivalvia di lokasi tersebut seragam. Pengukuran parameter lingkungan menunjukan komposisi substrat di Pantai Juata laut berupa lumpur berpasir yang memiliki banyak kandungan organik. Kualitas perairan di lokasi ini masih tergolong baik untuk kehidupan Bivalvia.
\end{abstract}

Kata kunci: Bivalvia, Keanekaragaman, Densitas, Distribusi, Faktor Fisiko-kimia

Diterima: 20 Agustus 2016, disetujui: 09 September 2016

\section{Pendahuluan}

Indonesia merupakan negara kepulauan terbesar di dunia yang memiliki garis pantai sepanjang 81,719 km, dengan keanekaragaman biota laut yang tinggi. Salah satu kekayaan perairan laut di Indonesia adalah kerang. Kerang merupakan hewan lunak bercangkang setangkup anggota Kelas Bivalvia Filum Mollusca. Bivalvia telah banyak dimanfaatkan diantaranya dagingnya untuk dikonsumsi, cangkang kerangnya digunakan untuk bahan kerajianan dan bahan pengolahan pakan ternak. Namun demikian data dasar mengenai keanekaragaman Bivalvia masih sangat terbatas dibandingkan dengan kerabat dekatnya, Kelas Gastropoda. Perairan laut yang luas, garis pantai yang panjang dan badan air yang banyak terdapat di hampir semua pulau di Indonesia menjadi habitat yang ideal untuk berbagai jenis kerang. 
Anggota Kelas Bivalvia memiliki adaptasi khusus yang memungkinkan spesies ini dapat bertahan hidup pada daerah yang memperoleh tekanan fisik seperti terjadi pada daerah intertidal. Organisme ini juga memiliki adaptasi untuk bertahan terhadap arus dan gelombang. Namun, anggota Kelas Bivalvia tidak memiliki kemampuan untuk berpindah tempat secara cepat, sehingga menjadi organisme yang sangat mudah ditangkap. Bivalvia merupakan biota yang bisa hidup di dalam substrat dasar perairan dalam waktu yang relatif lama, sehingga biasa digunakan sebagai bioindikator untuk menduga kualitas perairan dan merupakan salah satu komunitas yang memiliki keanekaragaman tinggi. Setiap habitat dasar memiliki perbedaan parameter lingkungan yang akan mempengaruhi struktur komunitas Bivalvia (Kennish, 1990).

Bivalvia tersebar di perairan pesisir seperti estuari, dengan dasar perairan lumpur bercampur pasir. Beberapa diantaranya hidup pada substrat yang lebih keras seperti lempung, kayu atau batu, air tawar serta sedikit yang hidup di daratan. Bivalvia seperti kapah (mussels), kerang (clamp) dan tiram merupakan anggota Bivalvia yang hidup di laut. Bivalvia yang hidup di daerah estuari, yaitu beberapa jenis kerang seperti Scrombicularia plana, Macoma balthica, Rangia flexosa dan tiram jenis Crassostrea (Nybakken, 1992).

Karakterisasi kerang terdapat pada sejumlah karakter cangkang kerang yang perlu diperhatikan, yaitu perbandingan ukuran atau dimensi (panjang, tinggi, diameter); bentuk cangkang; warna cangkang bagian luar dan dalam; bentuk dan tekstur lingkaran pertumbuhan; jumlah, bentuk, dan letak gigi kardinal dan lateral; dan garis pallial. Karakteristik utama Kelas Bivalvia antara lain: cangkang berengsel yang terdiri atas dua belah cangkang (kanan dan kiri) yang dihubungkan oleh suatu ligamen, baik badan maupun kaki pipih, tidak ada kepala, rongga mantel besar, cara hidup sendetary, tidak memiliki radula (Ruppert dan Barnes, 1994; Pechenick, 2000). Bekas perlekatan otot adduktor anterior dan otot adduktor posterior menjadi karakter taksonomi yang penting (Bretsky, 1976).

Bivalvia memiliki cangkang yang sangat bervariasi, baik dalam hal ukuran, bentuk, pahatan permukaan, maupun warna dan corak.
Menurut Morton (1984) ada beberapa bentuk cangkang, yaitu bersayap (wingged), dippershape, inequilateral, rhomboidal, lentivular, globular, triangular, berbentuk seperti jari (finger-shape), berbentuk seperti palu (hammershaped), serta tubuler. Selain itu, pahatan pada eksterior cangkang juga menjadi karakter taksonomi yang penting untuk Bivalvia. Tiga pahatan utama terdapat pada cangkang, yaitu rusuk radial yang berupa garis-garis konvergen menuju umbo, rusuk commarginal yang searah dengan garis pertumbuhan, dan rusuk diagonal oblique ribs (Morton, 1984).

Tarakan merupakan kota kecil yang terletak di Kalimantan Utara. Seluruh wilayah Kota Tarakan dikelilingi oleh laut, sehingga memungkinkan ditemukan berbagai jenis Bivalvia. Masyarakat Tarakan yang hidup di daerah pantai sebagian besar memiliki pekerjaan sebagai nelayan dan sebagai pengumpul anggota Kelas Bivalvia. Kondisi tersebut menyebabkan kemelimpahan Bivalvia di Kota Tarakan mengalami penurunan. Faktor lain yang menyebabkan menurunnya kemelimpahan Bivalvia di Kota Tarakan adalah dikembangkannya objek wisata Pantaim dan dibangunnya perusahaan udang dan ikan di daerah Pantai Juata Laut yang menyebabkan kerusakan ekosistem pantai. Hal ini diketahui, di beberapa pantai Kota Tarakan sudah tidak ditemukan lagi Bivalvia. Berdasarkan kondisi tersebut, maka diperlukan penelitian untuk mengetahui struktur komunitas dan distribusi anggota Kelas Bivalvia di Kota Tarakan. Selain itu, sampai saat ini belum ada kajian ilmiah dan publikasi tentang keanekaragaman dan pola distribusi anggota Kelas Bivalvia yang terdapat di Kota Tarakan, khususnya di Juata Laut

\section{Metode Penelitian}

Sampling Bivalvia dilakukan dengan metode transek. Di setiap pantai dibuat garis transek sepanjang 50 meter sejajar dengan garis pantai, kemudian dibuat garis subtransek dengan interval $10 \mathrm{~m}$. Plot ukuran $1 \mathrm{~m} \mathrm{x} 1 \mathrm{~m}$ diletakkan dari batas pasang tertinggi pasang air laut menuju batas terendah surut air laut, dengan interval $10 \mathrm{~m}$, sehingga terdapat 25 plot. Pada setiap plot, sampling Bivalvia dilakukan dengan 
dengan mengunakan alat pengeruk yang biasa digunakan oleh nelayan pencari kerang. Alat pengeruk terbuat dari besi mirip seperti cangkul, dengan panjang $40 \mathrm{~cm}$ dan lebar $10 \mathrm{~cm}$. Alat pengeruk ditancapkan di dasar perairan dan ditarik sejauh panjang transek yang telah ditentukan. Kerang yang ditemukan, dihitung jumlahnya dan untuk keperluan identifikasi, contoh spesimen dibawa ke laboratorium.

Pengukuran faktor fisiko-kimia yang dilakukan pada saat penelitian antara lain, pengukuran suhu, pengukuran kandungan substrat, pengukuran salinitas air, dan pengukuran kecerahan air. Analisis data dilakukan dengan menghitung densitas, Indeks Keragaman, Frekuensi, dan nilai penting.

\section{Hasil dan Pembahasan}

\section{Karakterisasi Ekosistem Pantai Juata Laut}

Secara geografis lokasi Pantai Juata laut, Kecamatan Tarakan Barat, Kelurahan Karang Harapan, Provinsi Kalimantan Utara terletak antara 03024'44,3" Lintang Utara (LU), 117031'18,6" Bujur Timur (BT), dan terletak pada ketinggian $10 \mathrm{mdpl}$ (Gambar 1). Lokasi ini ditempuh dengan menggunakan kendaraan air (Spedboat). Ekosistem lokasi penelitian di areal ini banyak terdapat pohon-pohon mangrove di sepanjang pantai dan terdapat sebuah aliran sungai.

Pengukuran parameter lingkungan menunjukan komposisi substrat di Pantai Juata laut berupa lumpur berpasir yang memiliki banyak kandungan organik. Pantai Juata Laut merupakan tipe pantai dengan tipe substrat lumpur berpasir, karena dipengaruhi oleh muara sungai dan melimpahnya pohon mangrove serta terdapat pohon-pohon nipah. Energi gelombang terdisipasi oleh hutan mangrove sehingga terjadi sedimentasi di dasar perairan.

Semakin halus tekstur substrat dasar maka kemampuan dalam menjebak bahan organik akan semakin besar. Hal ini menunjukan bahwa ukuran butir sedimen turut mempengaruhi kandungan bahan organik dalam sedimen atau dapat dikatakan semakin kecil ukuran partikel sedimen semakin besar kandungan bahan organiknya. Connaughey dan zattolly (1983) menyatakan partikel yang lebih halus mendorong lebih tingginya populasi bakteri. Dengan kemelimpahan bakteri yang lebih tinggi maka proses dekomposisi akan berlangsung lebih cepat sehingga akan menghasilkan bahan organik yang lebih banyak.

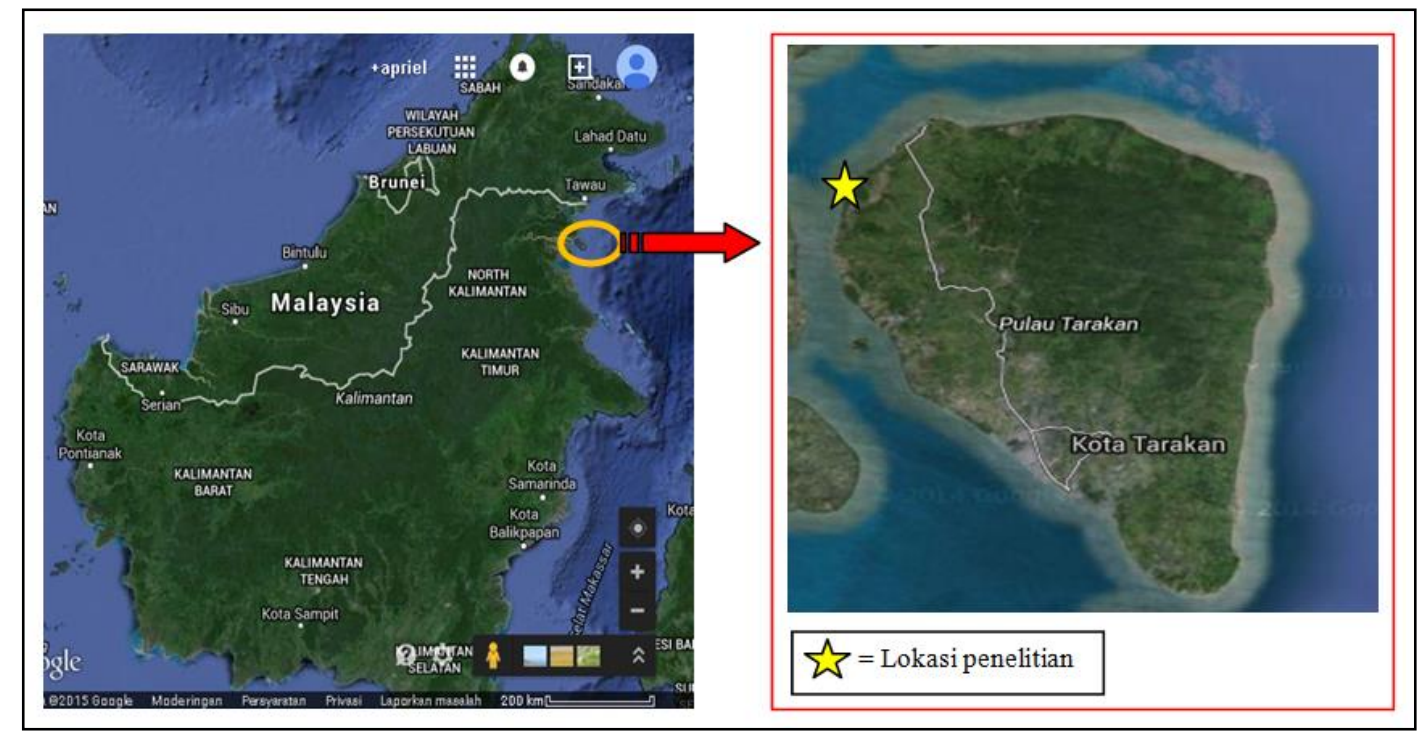

Gambar 1. Peta Lokasi Penelitian 


\section{Struktur Komunitas}

\section{Komposisi Jenis Bivalvia di Pantai Juata Laut}

Jumlah spesies Bivalvia yang ditemukan di Juata Laut sebanyak 2 spesies dari 2 famili. Famili tersebut adalah Arcidae dan Corbiludae. Anggota Famili Arcidae yang ditemukan di Pantai Juata laut adalah Anadara granosa sebanyak 38 individu, sedangkan anggota Famili Corbiludae yang ditemukan yaitu Polymesoda erosa sebanyak 7 individu (Tabel 1). Bivalvia yang paling banyak ditemukan adalah spesies Anadara granosa sebesar $84 \%$. Bivalvia yang paling sedikit ditemukan adalah Polymesoda erosa sebesar 16\% (Gambar 2).

Kerang jenis Anadara granosa yang terdapat di Pantai Juata Laut memiliki cangkang yang tebal serta kasar, hal ini dikarenakan cangkang memiliki gerigi. Anadara granosa hidup pada daerah mangrove yang memiliki substrat didominasi oleh lumpur berpasir. Menurut Carpenter (1998), ukuran maksimal Anadara granosa mencapai $9 \mathrm{~cm}$ (Gambar 3).
Sampel kerang yang diperoleh memiliki ukuran cangkang yang bervariasi. Ukuran terkecil dari ketebalan cangkang adalah 3,26 cm, dan ukuran terbesar dari ketebalan cangkang adalah $5,14 \mathrm{~cm}$. Untuk ukuran terkecil dari tinggi cangkang adalah 3,91 cm, dan ukuran terbesar dari tinggi cangkang adalah $5,76 \mathrm{~cm}$. Ukuran terkecil dari panjang cangkang adalah 4,67 cm, dan ukuran terbesar dari panjang cangkang adalah $6,64 \mathrm{~cm}$.

Kerang jenis Polymesoda erosa yang diperoleh di Pantai Juata Laut memiliki warna cangkang coklat. Kerang jenis ini memiliki cangkang tebal dan kuat, serta tekstur cangkang kasar dan mengkilat. Cangkang pada kerang Polymesoda erosa memiliki struktur seperti rambut, hal inilah yang membuat permukaan cangkangnya kasar. Polymesoda erosa merupakan kerang yang hidup didaerah mangrove. Carpenter (1998) menyatakan ukuran maksimal terbesar Polymesoda erosa mencapai $10,5 \mathrm{~cm}$ (Gambar 4).

Tabel 1. Komposisi Jenis Bivalvia di Pantai Amal dan Juata Laut

\begin{tabular}{clcc}
\hline \hline No & Nama Spesies & Famili & Jumlah \\
\hline \hline 1 & Anadara granosa & Arcidae & 38 \\
2 & Polymesoda erosa & Corbiludae & 7 \\
\hline \hline
\end{tabular}

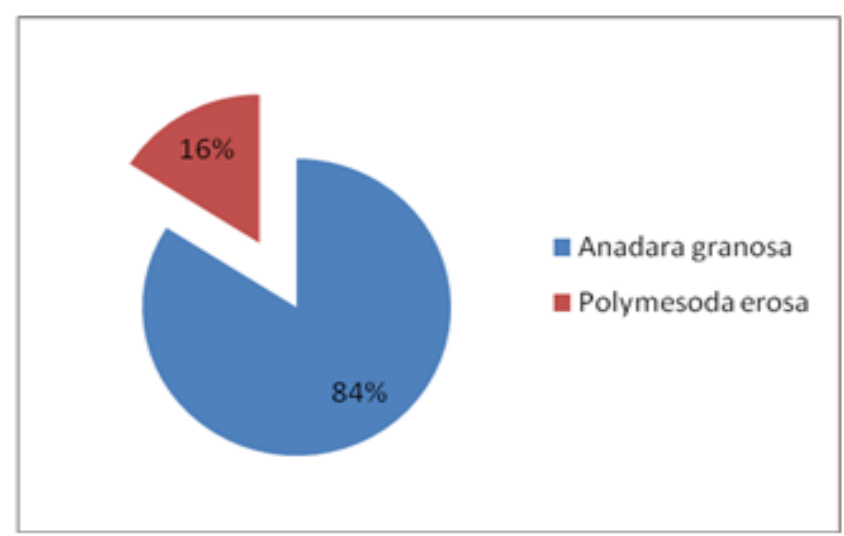

Gambar 2. Bivalvia yang ditemukan

\begin{tabular}{ll}
\multicolumn{2}{l}{ Anadara granosa } \\
Kerajaan & : Animalia \\
Divisi & : Moluska \\
Kelas & : Bivalvia \\
Bangsa & : Arcoida \\
Suku & : Arcidae \\
Marga & : Anadara \\
Spesies & : Anadara granos \\
(Carpenter and Niem, 1998)
\end{tabular}




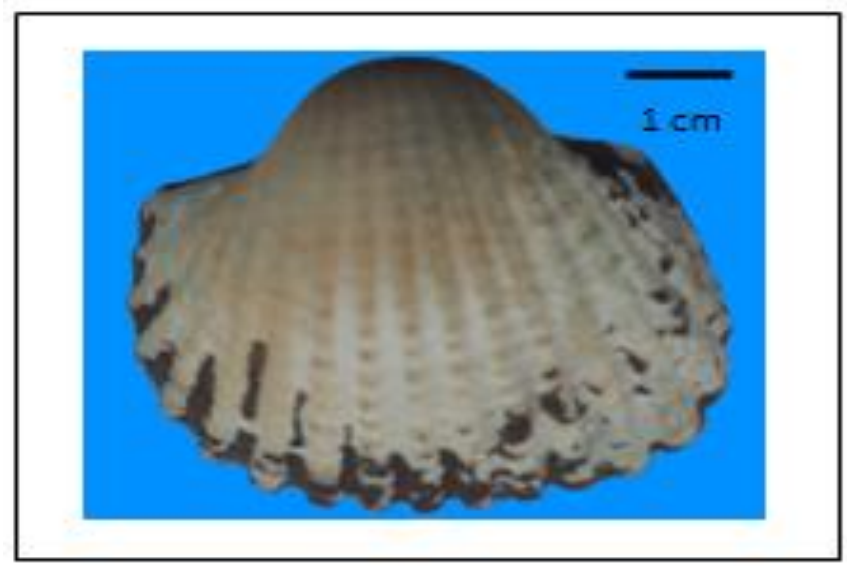

Gambar 3. Penampakan Cangkang Luar A. granosa (Dokumen Pribadi Agus, 2015).

Polymesoda erosa

Kerajaan : Animalia

Divisi : Moluska

Kelas : Bivalvia

Bangsa : Veneroida

Suku : Veneridae

Marga : Polymesoda

Spesies : Polymesoda erosa

(Carpenter and Niem, 1998)

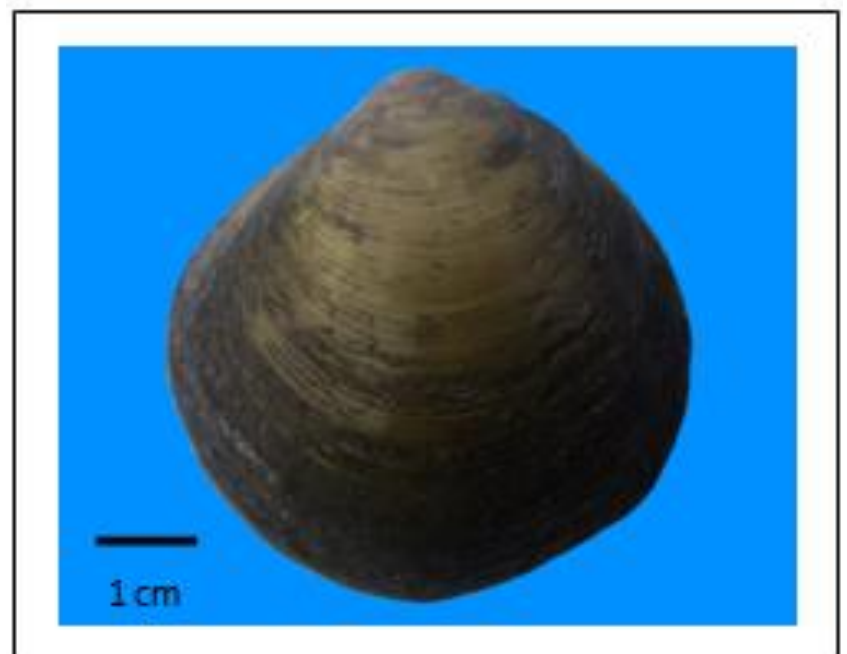

Gambar 4. Penampakan Cangkang Luar $P$. erosa (Dokumen Pribadi Agus, 2015). 
Pengukuran morfometrik cangkang dilakukan pada semua jenis kerang yang diperoleh untuk mengelompokkan kecil, sedang, dan besar Bivalvia yang dihitung berdasarkan ukuran panjang cangkang yang diperoleh pada saat penelitian (Tabel 2).

Menurut Carpenter (1998), ukuran maksimal Anadara granosa mencapai $9 \mathrm{~cm}$ dan ukuran maksimal Polymesoda erosa dapat mencapai $10 \mathrm{~cm}$. Berdasarkan pernyataan tersebut, kerang jenis Anadara granosa yang diperoleh di Pantai Juata laut hampir mendekati batas ukuran maksimalnya. Jenis Anadara granosa yang diperoleh di Pantai Juata laut memiliki ukuran besar dan kecil cangkang hampir merata. Sementara itu, ukuran Polymesoda erosa yang diperoleh di Pantai Juata laut berukuran sedang.

\section{Densitas, Frekuensi, dan Nilai Penting}

Densitas terbesar di Pantai Juata Laut adalah jenis Anadara granosa sebesar 0,84 ind $/ \mathrm{m} 2$, yang ditemukan di 11 plot dari total 25 plot sampling. Densitas terkecil adalah jenis Polymesoda erosa sebesar $0,16 \mathrm{ind} / \mathrm{m}^{2}$, yang ditemukan di 2 plot sampling dari total 25 plot sampling (Tabel 3).

Anadara granosa memiliki peranan yang sangat tinggi terhadap komunitas Bivalvia di Pantai Juata laut. Indeks Nilai Penting (INP) Anadara granosa sebesar 169,06\%. Hasil ini menunjukan bahwa adaptasi Anadara granosa terhadap kondisi lingkungan perairan Pantai Juata Laut sangat baik dan memberikan peranan yang besar terhadap struktur komunitas Bivalvia di Pantai Juata Laut. Jenis yang memiliki INP terendah menunjukkan bahwa jenis tersebut mempunyai peranan yang kecil terhadap struktur komunitas Bivalvia di Pantai Juata Laut.

\section{Pola Persebaran Jenis}

Pola sebaran Anadara granosa sebesar 0,28\%, berdasarkan Indeks Perhitungan Morisita, termasuk dalam pola sebaran seragam. Hal ini sangat berbeda dari kebiasaan hidup kerang jenis ini, karena pada umumnya Anadara granosa hidup secara mengelompok. Berdasarkan penelitian Carpenter (1998), Anadara granosa hidup secara mengelompok dan banyak ditemukan pada substrat yang kaya kadar organik. Pola sebaran secara seragam ini juga di pengaruhi oleh kondisi lingkungan. Di Pantai Juata Laut terdapat 1 aliran sungai yang dapat mempengaruhi pergerakan kerang. Pola sebaran Polymesoda erosa di Pantai Juata Laut berdasarkan nilai indeks perhitungan morisita diketahui secara seragam. Walaupun di Pantai Juata Laut adalah habitat yang baik untuk kehidupan kerang jenis ini, akan tetapi spesies tersebut jarang sekali ditemukan. Bila dilihat dari Faktor pendukung seperti melimpahnya Mangrove dan daerah sekitar Pantai Juata juga terdapat pohon nipah, seharusnya kondisi ini menjadi habitat yang sangat baik bagi kehidupan Polymesoda erosa. Hasan (2014) Mengatakan rumpun nipah memiliki berbagai ciri utama diantaranya adalah adanya akar serabut dengan bulu-bulu akarnya. Pada bulu-bulu akar ini tekumpul serasah tumbuhan yang dapat dimanfaatkan hewan dasar perairan sebagai makanannya terutama oleh kerang (Noor, dkk., 2006). Tamsar (2012), Polymesoda erosa merupakan salah satu jenis kerang yang banyak dijumpai hidup pada daerah hutan mangrove. Polymesoda erosa umumnya hidup dengan cara membenamkan diri di dalam dasar perairan (infauna).

\section{Indeks Keanekaragaman Jenis Bivalvia}

Indeks Nilai Keanekaragaman Jenis ( $H^{\prime}$ ) di Pantai Juata Laut sebesar 0,43 sehingga keanekaragaman Bivalvia dikategorikan rendah. Brower dkk., (1990) mengatakan nilai Indeks Keanekaragaman Jenis bila $\mathrm{H}^{\prime}<2$ maka dikategorikan keanekaragaman genera atau jenis rendah, kestabilan komunitas rendah, dan keadaan perairan telah tercemar. Odum (1993) mengatakan bahwa keanekaragaman jenis dipengaruhi oleh jenis habitat, tempat hidup, stabilitas lingkungan, produktifitas, kompetisi, dan penyangga makanan. Ketidakstabilan ekosistem disebabkan oleh pencemaran yang dihasilkan dari limbah perusahaan kayu dan udang di sekitar daerah Pantai Juata Laut.

\section{Parameter Perairan}

Hasil pengukuran kualitas perairan dapat dilihat pada Tabel 4. 
Tabel 2. Pengelompokan Ukuran Panjang Cangkang Bivalvia

\begin{tabular}{cllc}
\hline \hline No & Nama spesies & Panjang Cangkang $(\mathbf{c m})$ & Jumlah Individu \\
\hline \hline 1 & Anadara granosa & Kecil $(4,92-5,52)$ & 14 \\
& & Sedang $(5,53-6,20)$ & 13 \\
& & Besar $(6,21-6,98)$ & 11 \\
\hline \multirow{2}{*}{2} & Polymesoda erosa & Kecil $(4,93-5,59)$ & 2 \\
& & Sedang $(5,60-6,36)$ & 3 \\
& & Besar $(6,37-7,24)$ & 2 \\
\hline \hline
\end{tabular}

Tabel 3. Densitas, Frekuensi dan Indeks Nilai Penting

\begin{tabular}{ccccccccc}
\hline \hline No & Nama Spesies & $\sum$ Ind & $\begin{array}{c}\text { P Plot ditemukan } \\
\text { spesies }\end{array}$ & $\begin{array}{c}\text { D } \\
\left(\mathbf{i n d} / \mathbf{m}^{2}\right)\end{array}$ & $\begin{array}{c}\text { D.R } \\
(\boldsymbol{\%})\end{array}$ & $\begin{array}{c}\text { F } \\
(\boldsymbol{\%})\end{array}$ & $\begin{array}{c}\text { FR } \\
(\boldsymbol{\%})\end{array}$ & $\begin{array}{c}\text { INP } \\
(\boldsymbol{\%})\end{array}$ \\
\hline \hline 1 & A. granosa & 38 & 11 & 0,84 & 84,44 & 0,85 & 84,62 & 169,06 \\
2 & P. erosa & 7 & 2 & 0,16 & 15,56 & 0,15 & 15,38 & 30,94 \\
\hline \hline & Jumlah & & & $\mathbf{1 , 0 0}$ & $\mathbf{1 0 0 , 0 0}$ & $\mathbf{1 , 0 0}$ & $\mathbf{1 0 0 , 0 0}$ & $\mathbf{2 0 0 , 0 0}$ \\
\hline \hline
\end{tabular}

Keterangan: D = Densitas, D.R = Densitas Relatif, F= Frekuensi, FR= Frekuensi Relatif, INP = Indeks Nilai Penting

Tabel 4. Parameter Lingkungan

\begin{tabular}{clcc}
\hline \hline No & Parameter & PJL & Baku Mutu \\
\hline \hline 1 & Suhu $\left({ }^{0} \mathrm{C}\right)$ & 31 & $25-31$ \\
2 & Salinitas $\%$ oo $(\mathrm{m} / \mathrm{s})$ & 25 & $25-40$ \\
3 & Kecepatan arus & 0.29 & - \\
4 & Oksigen Terlarut & 5,17 & - \\
\hline \hline
\end{tabular}

\section{Suhu}

Suhu merupakan faktor pembatas bagi beberapa fungsi fisiologis hewan air seperti migrasi, pemijahan, efisiensi makanan, kecepatan renang, perkembangan embrio, dan kecepatan metabolisme (Priosambodo, 2011). Suhu juga dapat berpengaruh terhadap perkembangan organisme parasit dan penyakit. Suhu di Pantai Juata Laut tergolong sesuai untuk kehidupan Moluska, khususnya Bivalvia, yang pada umumnya dapat hidup pada kisaran suhu yang luas karena morfologi dari Bivalvia sendiri adalah memiliki pelindung berupa cangkang, sehingga dapat bertahan pada suhu tertentu yang cukup tinggi.

\section{Salinitas}

Berdasarkan penelitian ini, kadar salinitas di pantai Juata Laut masih layak bagi kehidupan makrozoobenthos. Menurut Vonk dkk., (2008) mengatakan bahwa kisaran salinitas untuk kehidupan makrozoobenthos adalah $24 \%$ $40 \%$ o.

\section{Kecepatan Arus}

Arus di perairan Pantai Juata Laut memiliki kecepatan $\pm 0,29 \mathrm{~m} / \mathrm{s}$. Faktor yang memicu kecepatan arus adalah angin, dan faktor yang bisa memperlambat pergerakan arus adalah tingkat kedangkalan perairan dan tegakan lamun. Arus yang deras tidak baik bagi kehidupan lamun dan Bivalvia. Kecepatan arus yang tinggi akan mengaduk sedimen di dasar perairan pantai, hal ini akan membuat perairan tersebut dapat menjadi keruh dan mempengaruhi proses fotosintesis pada lamun sehingga akan berpengaruh pada kandungan oksigen terlarut dalam perairan.

\section{Oksigen terlarut (DO)}

Kandungan oksigen di perairan Pantai Juata Laut sangat mendukung kehidupan yang ada dalam perairan. Patrick (1977) menjelaskan bahwa kisaran oksigen terlarut minimal antara 3,0 mg/l - 5,0 mg/l termasuk baik, di atas 7,0 $\mathrm{mg} / \mathrm{l}$ termasuk produksi tinggi dan kandungan oksigen terlarut minimal 2,0 mg/l sudah cukup mendukung kehidupan organisme perairan secara normal. 


\section{Simpulan}

Struktur komunitas Bivalvia di Pantai Juata Laut terdiri dari Anadara granosa dan Polymesoda erosa. Distribusi Bivalvia di Pantai Juata Laut seragam. Densitas dan Indeks Nilai Penting Bivalvia tertinggi di Pantai Juata laut adalah Anadara granosa. Keanekaragaman jenis Bivalvia di Pantai Juata Laut termasuk dalam kategori rendah.

\section{Daftar Pustaka}

Bretsky, S.S. 1976. Evolution and Classification of the Lucinidae (Mollusca; Bivalvia). Palaeontographica Americana 8: 219-337.

Brower, J.E., Zar, J.H. dan Von Ende. 1990. General Ecology, Field, and Laboratory Methods for General Ecology. Ed ke-3 Iowa: America WM. C. Brown Companv publisher Dubugue.

Carpenter, E.K. dan Niem, V.H. 1988. The Living Marine Resources of the Western central Pacific. Volume 1. Seaweeds, Corals, Bivalves and Gastropoda. United Nation: 688

Hasan, U., Wahyuningsih, H. dan Jumilawati, E. 2014. Kepadatan dan Pola Pertumbuhan Kerang Lokan (Gelonia erosa, Solander 1786) di Ekosistem Mangrove Belawan. Jurnal Perikanan dan Kelautan, 19 (2) : 42-49

Kennish. 1990. Ecology Estuaries. Vol 2 : Biological aspect. CRC Press. New Jersey. USA 391 p.

Morton, B. 1984. A review of Polymesoda (Geloina0 Gray, 1842 (Bivalve: Corbiculidae) from Indo Pasific mangrove. Asian Marine Biology, 1: 77-86.

Noor, Y.R., Khazali, M. dan Suryadiputra, I.N.N. 2006. Panduan Pengenalan Mangrove di Indonesia. Wetland International Indonesia Programme. Bogor.
Nybakken, J.W. 1992. Biologi Laut, Suatu Pendektan Ekologis. PT Gramedia Pustaka: Jakarta. Halaman 458.

Nybakken, J.W. 1993. Marine Biology: An Ecological Approach. Third Edition. Harper Collins College Publishers.

Odum, E.P. 1994. Dasar-dasar Ekologi (Terjemahan) Edisi ke tiga. Gadjah Mada University Press: Yogyakarta

Patrick, W.H.Jr. dan Delaune, R.D. 1977. Chemical and Biological Redox Systems Affecting Nutrient Availability in the Coastal Wetlands. Geoscience and Man, 18: 131137.

Pechenik, J.A. 2000. Biology of the Invertebrates, Fourth Edition. Mc. Graw-Hill Companies, Inc.

Priosambodo, D. 2011. Struktur Komunitas Makrozoobentos di daerah Padang Lamun Pulau Bone Batang Sulawesi Selatan. Thesis. Sekolah Pascasarjana Universitas Negeri Malang.

Ruppert, Edward, E. dan Robert, D. Barnes. 1994. Invertebrate Zoology, Sixth Edition. Saunders College Publishing, Harcourt Brace and Company, Orlando, Florida. Hardcover. 1100 pages.

Tamsar. 2012. Aspek Pertumbuhan Kerang Kalandue (Polymesoda erosa) di Perairan Hutan Mangrove Teluk Kendari Sulawesi Tenggara. Skripsi. Universitas Halu Oleo. Kendari.

Vonk, J.A., Kneer, D., Stapel, J. dan Asmus, H. 2008. Shrimp burrow in tropical seagrass meadow: an important sink for litter. Estuarine Coast. Shelf.Sci., 79: 79. 